\title{
Sarcoma of the Orbit Pathologic TNM Finding v7
}

National Cancer Institute

\section{Source}

National Cancer Institute. Sarcoma of the Orbit Pathologic TNM Finding v7. NCI

Thesaurus. Code C88809.

A pathologic finding about one or more characteristics of sarcoma of the orbit, following the rules of the TNM AJCC V7 classification system. The nature of the histopathology specimen (fine-needle aspiration biopsy, excisional biopsy, lumpectomy, or total excision) should be noted. Pathologic classification is based on the specific histopathology of the tumor, its differentiation (grade), and the extent of removal (evaluation of the excisional margins). In total excision specimens, evaluation of the surgical margins is mandatory. (from AJCC 7th Ed.) 